\title{
Analisis Sifat Mekanik dan Permeabilitas Pasir Cetak Menggunakan Bahan Campuran Kaolin Pada Sand Casting
}

\author{
Nanda Rizki Acmad Diasa Putra ${ }^{1)}$, Putut Murdanto ${ }^{2)}$, dan Wahono ${ }^{3)}$ \\ 1,2,3 Program Studi S1 Pendidikan Teknik Mesin Jurusan Teknik Mesin \\ ${ }^{1,2,3}$ Fakultas Teknik Universitas Negeri Malang \\ 1,2,3 Jalan Semarang No. 5, Malang 65145 \\ e-mail: nanda.diasa@gmail.com
}

\begin{abstract}
Abstrak : Sand Casting atau cetakan pasir merupakan suatu cetakan yang umum digunakan pada teknik pengecoran logam Kaolin merupakan masa batuan yang tersusun dari material lempung berwarna putih atau krem. Tujuan penelitian ini adalah untuk mengetahui pengaruh campuran kaolin terhadap sifat mekanik dan permeabilitas pada kondisi pasir basah dan kering. Metode yang digunakan dalam penelitian ini adalah experimental dengan pendekatan deskriptif. Bahan campuran kaolin dibuat bervariasi sebesar $1 \%, 4 \%, 7 \%, 10 \%$, dan 13\%. Temuan penelitian yang didapatkan yaitu: (1) kekautan tarik tertinggi terdapat pada variasi kaolin $13 \%$ yaitu sebesar $0,07 \mathrm{Kg} / \mathrm{cm}^{2}$, (2) kekuatan tekan tertinggi terdapat pada variasi kaolin $13 \%$ sebesar $3,11 \mathrm{Kg} / \mathrm{cm}^{2}$, (4) kekuatan geser tertinggi terdapat pada vaiasi kaolin $7 \%$ sebesar $0,46 \mathrm{Kg} / \mathrm{cm}^{2}$, (5) permeabilitas tertinggi terdapat pada variasi kaolin $10 \%$ sebesar $230 \mathrm{ml} /$ menit, (6) variasi $1 \%$ dan $4 \%$ tidak dapat digunakan karena pada saat pembuatan spesimen atau sampel terjadi ambrol atau hancur.
\end{abstract}

Kata kunci: Sand Casting, Kaolin, Sifat Mekanik, Permeabilitas

\begin{abstract}
Abstrack: Sand Casting is a mold commonly used in metal casting techniques. Kaolin is a period of rock composed of white or beige clay material. The purpose of this study was to determine the effect of kaolin mixture on mechanical properties and permeability on green and dry sand molding. The method used in this study is experimental with a descriptive approach. The ingredients of the kaolin mixture were varied by $1 \%, 4 \%, 7 \%, 10 \%$, and $13 \%$. The research findings obtained are: (1) the highest tensile strength is found in the variation of $13 \%$ kaolin which is $0.07 \mathrm{Kg} / \mathrm{cm}^{2},(2)$ the highest compressive strength is found in the variation of $13 \%$ kaolin at $3.11 \mathrm{Kg} / \mathrm{cm}^{2}$, (4) the highest shear strength was found in $7 \%$ kaolin vaiasi of 0.46 $\mathrm{Kg} / \mathrm{cm}^{2}$, (5) the highest permeability was found in $10 \%$ kaolin variation of $230 \mathrm{ml} /$ minute, (6) variations of $1 \%$ and $4 \%$ could not be used because at the time of specimen making or the sample happens to crack or destroyed.
\end{abstract}

Keywords: Sand Casting, Kaolin, Mechanical Properties, Permeability

Pengecoran logam adalah suatu proses produksi pembuatan benda ataupun produk dengan cara mencairkan logam kemudian dituangkan kedalam rongga cetakan, untuk mendapatkan hasil coran yang berkualitas maka diperlukan teknik desain cetakan dan pemahaman sifat logam serta praktikum pengecoran logam. Menurut Puspitasari dan Khafiddin (2014:1) menyatakan bahwa pengecoran (Casting) merupakan suatu teknik pembuatan produk dengan cara logam dicairkan kedalam tungku peleburan dalam kurun waktu tertentu untuk selanjutnya dituang dalam rongga cetakan yang serupa dengan bentuk asli dari produk cor yang akan dibuat.

Meskipun banyak teknologi canggih baru untuk pengecoran logam, pengecoran pasir cetak tetap menjadi cetakan yang paling banyak digunakan karena biaya bahan baku yang rendah, bermacam-macam ukuran dan komposisi, serta kemungkinan daur ulang pasir cetakan. Pembuatan pasir cetak merupakan salah satu tahapan yang penting dalam proses pengecoran logam. Hal ini dikarenakan komposisi bahan-bahan yang digunakan dalam proses pembuatan pasir cetak akan mempengaruhi daya ikat pada pasir tersebut.

Cetakan Pasir adalah suatu cetakan pada teknik pengecoran yang terbuat dari pasir dimana sebelumnya sudah diberi tambahan atau campuran berupa bahan pengikat dan air dengan kadar yang sudah ditentukan. Pada penelitian ini, pasir yang akan digunakan adalah jenis pasir silika buatan dengan alasan harga yang terjangkau dan pasir sudah teruji serta layak untuk digunakan. Sedangkan bahan pengikat pada penelitian-penelitian ataupun praktikum pengecoran yang lazim digunakan adalah bentonit karena memang sudah teruji dan menghasilkan produk yang bagus. Akan tetapi pada penelitian ini peneliti akan menggunakan kaolin sebagai campuran bentonit yang berasal dari Ngeni daerah Blitar selatan dengan variasi atau persentase $1 \%, 4 \%, 7 \%, 10 \%$, dan $13 \%$.

Haine ( dalam Zuhri, 2014: 12) penggunaan pasir cetak ada dua macam, yaitu: cetakan pasir basah dan cetakan pasir kering. Pada dasarnya perbedaan jenis cetakan tersebut adalah pada cetakan kering yaitu perlakuan panas dengan pengovenan. Kaolin merupakan masa batuan yang tersusun dari material lempung yang berwarna putih atau krem, kaolin juga memiliki komposisi hidrous aluminium silikat (2H2O Al2O3 $2 \mathrm{SiO} 2)$ yang diikuti oleh material lainya. Kandungan kimia pada kaolin terdiri atas 39\% oksida alumina, 47\% oksida silika, dan 14\% air (Sukamta dalam Frida dkk, 2014). 
Pemanfaatan kaolin sendiri saat ini digunakan sebagai bahan baku kaca, marmer, keramik, dan lain sebagainya. Sepintas komposisi dan karakteristik kaolin dengan bentonit hampir sama seperti yang dijabarkan oleh Jambise, dkk (2014) pada tabel dibawah ini.

Tabel 1. Karakteristik Bentonit dan Kaolin

\begin{tabular}{cccc}
\hline No & Karakteristik & Bentonit & Kaolin \\
\hline 1 & Kadar air & 13,4 & 0,3 \\
2 & Berat jenis & 2,72 & 2,59 \\
3 & Liquid limit & $132,10 \%$ & $88,47 \%$ \\
4 & Plastic limit & $45,05 \%$ & $43,08 \%$ \\
5 & Shringkage limit & $39,84 \%$ & $6,37 \%$ \\
6 & Indeks plastisitas & $87,05 \%$ & $45,40 \%$ \\
\hline
\end{tabular}

(Sumber: Jambise, dkk ,2014:131)

Pengujian kekuatan sifat mekanik merupakan pengujian yang dilakukan untuk mengetahui sifat mekanik material. Sifat mekanik merupakan sifat material yang muncul akibat pembebanan secara mekanik.pengujian sifat mekanik dibedakan menjadi tiga yaitu; 1)kekuatan tarik adalah tegangan maksimal yang mampu ditahan oleh bahan atau material saat diregangkan atau ditarik dan sampai material atau bahan sebelum mengalami patah, 2)kekuatan tekan yaitu kekuatan atau kemampuan cetakan menahan ataupun menerima gaya tekan yang diberikan oleh logam cair pada saat cairan logam tersebut mengalir pada cetakan yang mengisi ruangan sesuai bentuk pola, 3)kekuatan geser adalah kemampuan suatu pasir untuk memikul gaya yang dapat menyebabkan pergeseran dan keruntuhan tanah.

Pengujian permeabilitas dilakukan dengan tujuan mengetahui kemampuan cetakan untuk dapat mengalirkan gas-gas ataupun udara dan uap air yang terjebak didalam cetakan. Oleh sebab itu diantara butir-butir pasir perlu adanya ruang supaya gas yang berasal dari cetakan dan logam cair dapat melepaskan diri selama waktu penuangan, sehingga tidak ada udara yang terjebak didalamnya.

\section{METODE PENELITIAN}

Pada penelitian ini memiliki tujuan utama yaitu untuk mengetahui pengaruh penggunaan kaolin sebagai bahan campuran pada pasir cetak kering dan juga basah dengan melakukan pengujian sifat mekanik dan permeabilias. Metode pendekatan yang digunakan adalah penelitian deskriptif kuantitatif. Menurut Arikunto (2013: 3), analisis deskriptif meruapakan penjabaran penelitian yang benar-benar terjadi apa adanya dalam sebuah kancah, lapangan, atau wilayah tertentu, data dikelompokan menurut jenis sifat atau kondisi untuk disimpulkan.

Dengan jenis penelitian eksperimental menggunakan desain Pre-experimental dengan model One-Shot Case Study Dimana sekelompok sampel diberi sebuah perlakuan dan selanjutnya dan selanjutnya di analisis hasilnya. Jika digambarkan dalam bentuk bagan maka

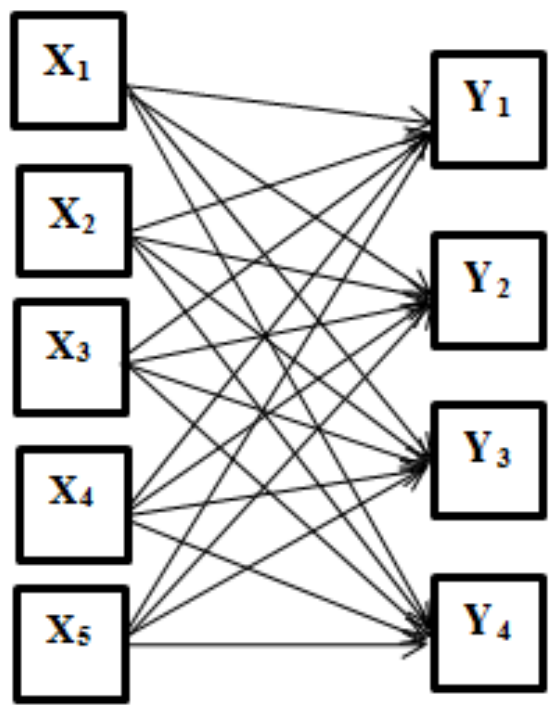

Gambar 1 Desain Penelitian yang Digunakan 
Dengan keterangan: $\mathrm{X}_{1}=$ Kaolin $1 \%, \mathrm{X}_{2}=$ Kaolin $4 \%, \mathrm{X}_{3}=$ Kaolin $7 \%, \mathrm{X}_{4}=$ Kaolin $10 \%, \mathrm{X}_{5}=\mathrm{Kaolin}_{13} \%, \mathrm{Y}_{1}=$ Permeabilitas, $\mathrm{Y}_{2}=$ Kekuatan Tarik, $\mathrm{Y}_{3}=$ Kekuatan Tekan, $\mathrm{Y}_{4}=$ Kekuatan Geser.

Dengan jenis variable penelitian variable bebas: persentase air dan persentase kaolin, variable terikat: sifat mekanik dan permeabilitas, dan variable terkonrol: air 5\% dan bentonit 2\%. Maka alur pelaksanaan penelitiannya adalah sebagai berikut:

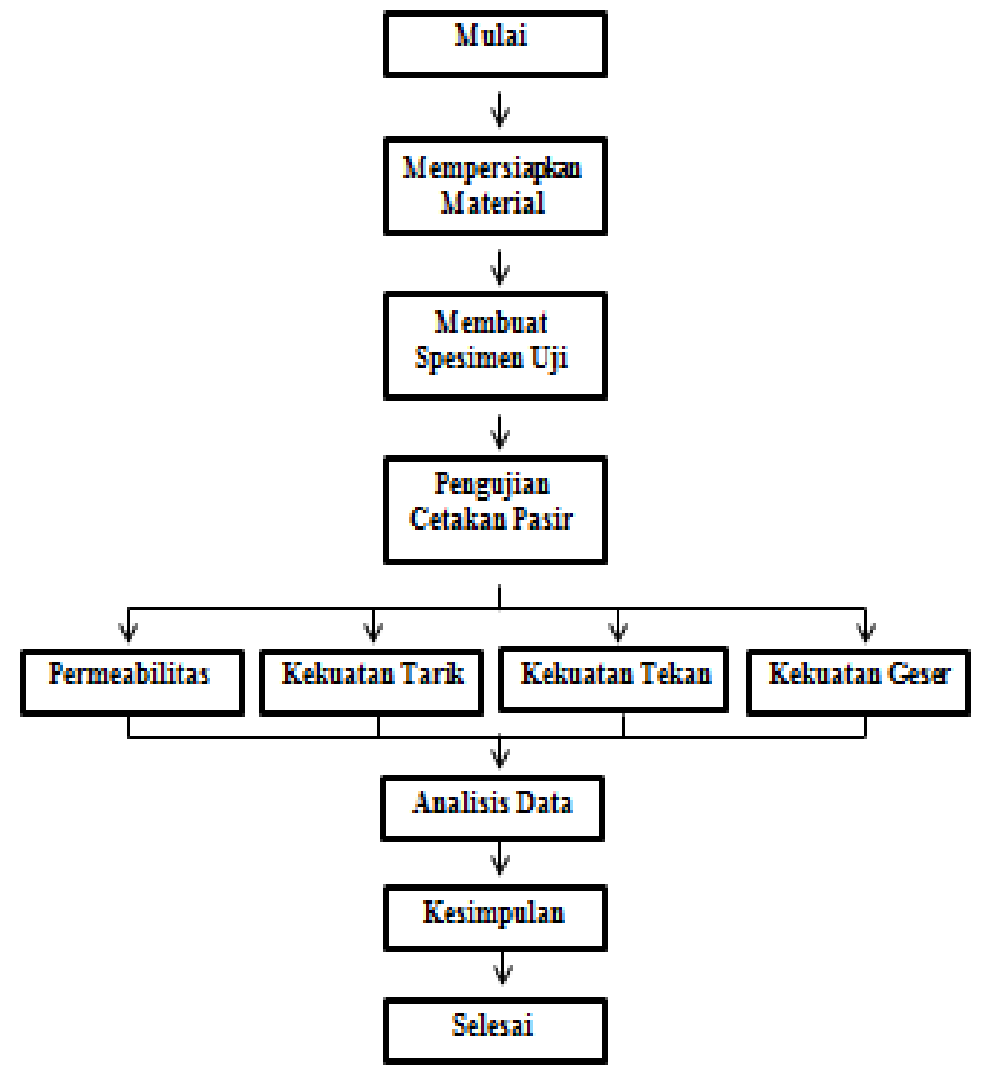

Gambar 2. Alur Pelaksanaan Penelitian

Dalam pengujian spesimen pada kekuatan mekanik dan permeabilitas tentunya memiliki bentuk yang berbeda, berikut bentuk specimen uji:

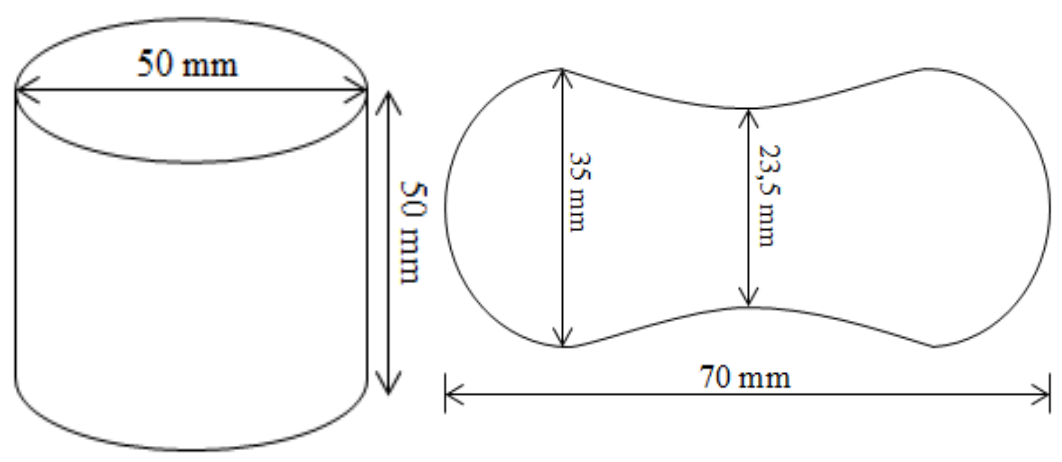

Gambar 3. Spesimen Uji Kekuatan Mekanik dan Permeabilitas.

(Sumber: Laboratorium Pengecoran Logam Jurusan Mesin Fakultas Teknik Universitas Brawijaya)

Berdasarkan data yang didapat dari modul praktikum proses manufaktur II Laboraturium Pengecoran Universitas Brawijaya Malang langkah yang dilakukan dalam melakukan pengujian kekuatan sifat mekanik yaitu: (1) Ambil campuran pasir cetak seberat 150 gr, kemudian buat spesimen uji tarik dengan menggunakan sand ramer (spesimen sebanyak 3 buah), (2) 
pasang kepala uji tarik/tekan/geser pada alat uji kekuatan pasir cetak, (3) letakkan spesimen pada kepala uji tarik/tekan/geser pasir cetak secara hati - hati jangan sampai rusak, (4) putar handwheel secara terus menerus dengan putaran konstan dan perlahan - lahan hingga spesimen hancur, (5) baca dan catat besar kekuatan tarik pasir cetak tersebut (lengkap dengan satuannya) pada skala paling dalam yang terdapat pada alat uji tarik pasir cetak, (6) lakukan langkah $1-5$ pada spesimen berikutnya.

Langkah pengujian spesimen tanpa perlakuan panas sama dengan tanpa perlakuan panas, bedanya setelah pasir cetak dibentuk spesimen uji tarik dilakukan pemanasan ke dalam dapur pemanas dengan suhu $110^{\circ} \mathrm{C}$ selama 1 jam.

\section{HASIL DAN PEMBAHASAN}

Setelah penelitian dilakukan sesuai dengan rancangan penelitian ,maka diperoleh hasil pengujian

Tabel 2 uji komposisi kaolin

\begin{tabular}{ccc}
\hline Kandungan & Persentase (\%) & Metode \\
\hline $\mathrm{Si}$ & 42,0 & \\
$\mathrm{~K}$ & 28,7 & \\
$\mathrm{Ti}$ & 2,01 & \\
$\mathrm{~V}$ & 0,088 & \\
$\mathrm{Cr}$ & 0,064 & \\
$\mathrm{Mn}$ & 0,57 & $\mathrm{XRF}$ \\
$\mathrm{Fe}$ & 25,5 & \\
$\mathrm{Cu}$ & 0,13 & \\
$\mathrm{Zn}$ & 0,089 & \\
$\mathrm{Rb}$ & 0,41 & \\
$\mathrm{Eh}$ & 0,3 & \\
$\mathrm{Re}$ & 0,1 & \\
\hline
\end{tabular}

Dari hasil penelitian yang didapatkan bahwa kandungan Silikon (Si) yang mendominasi, yaitu dengan persentase $42 \%$ . Sama halnya dengan penelitian yang dilakukan oleh yani, dkk (2013:1) menyebutkan bahwa pengujian XRF pada kaolin Capkala Kalimantan juga didominasi oleh Si sebesar 48,2\%. Silikon/silika (Si) sendiri memiliki sifat tahan temperatur tinggi, mengikat air,dan meningkatkan kekerasan (bahtiar dan Soemardji,2012:315).

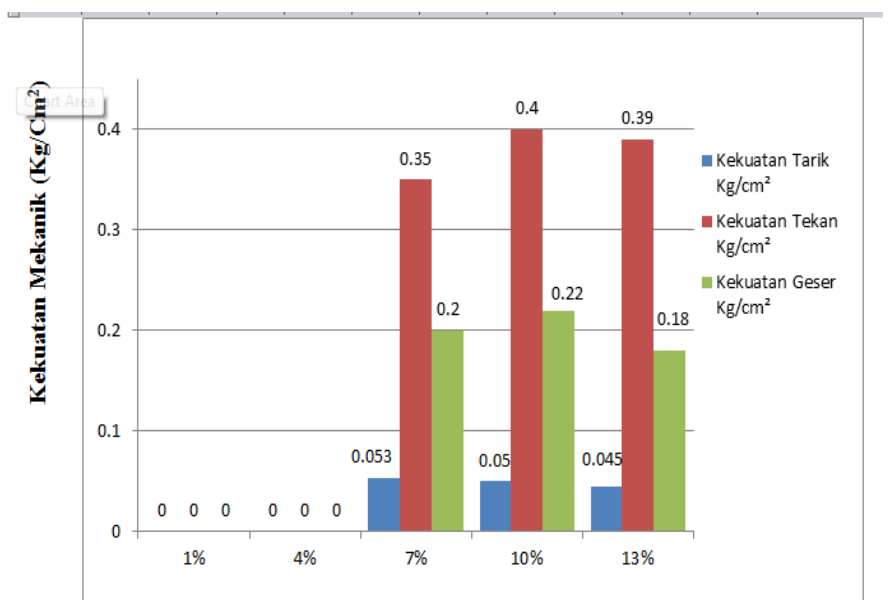

Gambar 4 Diagram Batang Analisis Sifat Mekanik Cetakan Pasir Basah Terhadap Variasi Kaolin

Dari hasil pengujian kekuatan mekanik pada kondisi pasir basah didapatkan kekuatan tarik tertinggi pada cetakan basah terdapat pada cetakan pasir sampel 3 (kaolin 7\%) dengan kekuatan $0.053 \mathrm{Kg} / \mathrm{Cm}^{2}$, kemudian cetakan pasir sampel 4 (kaolin 10\%) dengan kekuatan $0,05 \mathrm{Kg} / \mathrm{Cm}^{2}$, dan kekuatan cetakan pasir sampel 5 (kaolin 13\%) dengan kekuatan 0,045 $\mathrm{Kg} / \mathrm{Cm}^{2}$, sementara pada sampel 1 dan 2 tidak diketahui hasilnya karena pada saat pembuatan spesimen terjadi ambrol atau hancur. Dari data diatas dapat disimpulkan bahwa pemakaian bahan campuran kaolin pada cetakan basah dapat digunakan dengan persentase minimal $7 \%$ yang dicampur bentonit $2 \%$, serta dengan dilakukan penambahan persentase kaolin akan mengakibatkan menurunnya kekuatan tarik pada cetakan pasir 
Pengujian kekuatan tekan pada kondisi cetakan pasir basah, kekuatan tekan tertinggi berada pada cetakan pasir sampel 4 (kaolin $10 \%$ ) dengan kekuatan tekan mencapai $0,4 \mathrm{Kg} / \mathrm{Cm}^{2}$, disusul dengan cetakan pasir sampel 5 (kaolin $13 \%$ ) dengan kekuatan tekan $0,39 \mathrm{Kg} / \mathrm{Cm}^{2}$, selanjutnya kekuatan tekan menurun pada cetakan pasir sampel 3 (kaolin 7\%) yaitu sebesar 0,353 $\mathrm{Kg} / \mathrm{Cm}^{2}$. Sementara pada cetakan pasir sampel 1 dan 2 tidak diketahui hasilnya karena pada saat pembuatan spesimen terjadi ambrol atau hancur. Dari data tersebut dapat ditarik kesimpulan bahwa pemakaian bahan campuran kaolin pada cetakan pasir basah dapat digunakan dengan persentase minimal 7\% yang dicampur bentonit $2 \%$, dan dengan penambahan persentase kaolin akan membuat kekuatan tekan bertambah .

Pengujian kekutan geser pada cetakan pasir basah, dimana kekutan geser tertinggi terdapat pada cetakan pasir sampel 4 (kaolin $10 \%$ ) dengan nilai kekuatan geser $0,22 \mathrm{Kg} / \mathrm{Cm}^{2}$, selanjutnya diikuti oleh cetakan pasir sampel 3 (kaolin $7 \%$ ) dengan nilai kekuatan geser $0,19 \mathrm{Kg} / \mathrm{Cm}^{2}$, pada cetakan pasir sampel 5 (kaolin $13 \%$ ) didapatkan menurunnya kekuatan geser menjadi $0,173 \mathrm{Kg} / \mathrm{Cm}^{2}$.

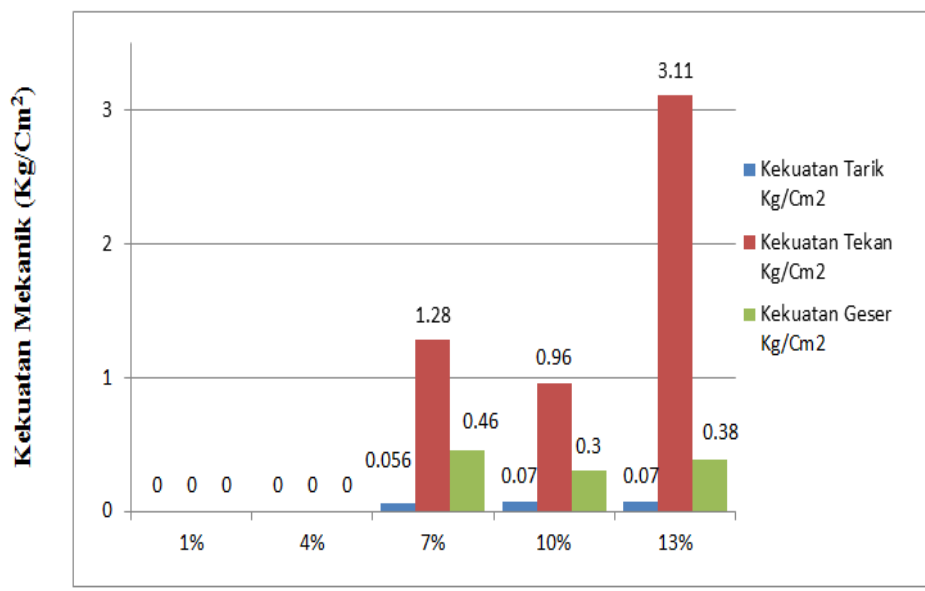

Gambar 5 Diagram Batang Analisis Sifat Mekanik Cetakan Pasir Kering Terhadap Variasi Kaolin

Kekuatan cetakan pasir kering mengalami naik turun atau bertambah dan berkurangnya kekuatan seiring bertambahnya persentase kaolin. Apabila dibandingkan dengan cetakan pasir basah, pasir kering memiliki hasil yang lebih baik. Pada hasil cetakan pasir kering kekuatantarik tertinggi terdapat pada sampel 5 ( kaolin 13\%) dan diikuti oleh sampel 4(kaolin 7\%) terbaca sebesar $0,07 \mathrm{Kg} / \mathrm{Cm}^{2}$, selanjutnya diikuti oleh sampel 3(kaolin 7\%) dengan kekuatan sebesar 0,056 Kg/Cm² ${ }^{2}$ Sementara pada cetakan pasir sampel 1 dan 2 tidak diketahui hasilnya karena pada saat pembuatan spesimen terjadi ambrol atau hancur.

Kekuatan tekan pada cetakan pasir kering, kekuatan tertinggi didapatkan pada sampel 5 (kaolin 13\%) sebesar 3,11 $\mathrm{Kg} / \mathrm{Cm}^{2}$, disusul dengan kekuatan tekan cetakan pasir kering sampel 3 (kaolin 7\%) sebesar 1,28 $\mathrm{Kg} / \mathrm{Cm}^{2}, \mathrm{kekuatan}$ tertinggi selanjutnya dimiliki oleh cetakan pasir kering sampel 4 (kaolin $10 \%$ ) sebesar $0,96 \mathrm{Kg} / \mathrm{Cm}^{2}$. Sementara pada cetakan pasir sampel 1 dan 2 tidak diketahui hasilnya karena pada saat pembuatan spesimen terjadi ambrol atau hancur.

Kekuatan geser pada cetakan pasir kering. Kekuatan tertinggi didapatkan pada cetakan pasir kering sampel 3 (kaolin $7 \%$ ) sebesar $0,46 \mathrm{Kg} / \mathrm{Cm}^{2}$, kemudian disusul oleh cetakin pasir kering sampel 5 (kaolin $13 \%$ ) sebesar $0,38 \mathrm{Kg} / \mathrm{Cm}^{2}$, dan selanjutnya cetakan pasir kering sampel 4 (kaolin $10 \%$ ) sebesar $0,3 \mathrm{Kg} / \mathrm{Cm}^{2}$. Sama halnya dengan pengujian pada kekuatan tekan, pada pengujian kekuatan geser juga mengalami hal yang serupa penurunan pada sampel 4 (kaolin 10\%) akan tetapi tidak signifikan. Hal tersebut terjadi didasari akibat masalah teknis pada saat pembuatan sampel.

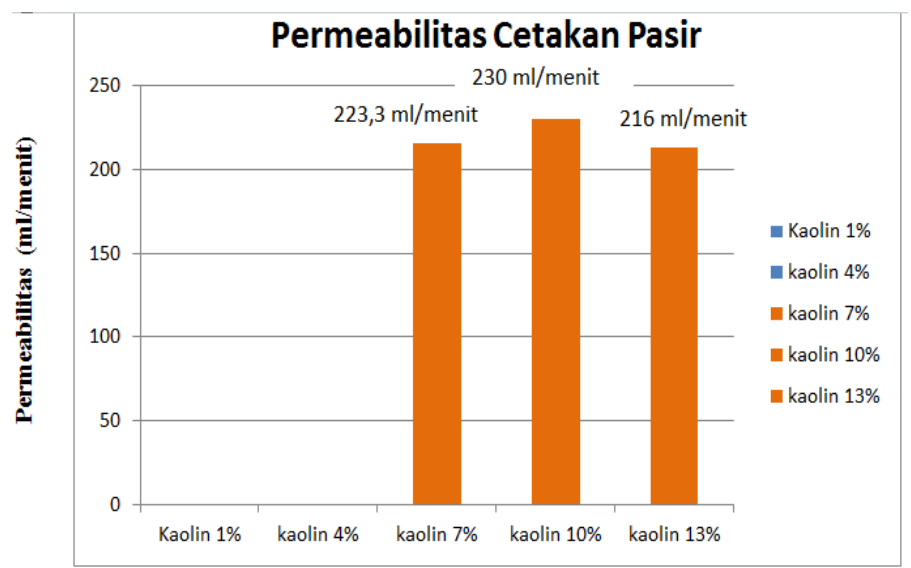

Gambar 6 Diagram Batang Hasil Pengujian Permeabilitas Cetakan Pasir Terhadap Variasi Kaolin 
Dari gambar diagram batang 6 diatas menunjukkan bahwa cetakan pasir dengan perlakuan dipanaskan $110^{\circ} \mathrm{C}$ selama 60 menit permeabilitas tertinggi berada pada sampel sampel 4 (kaolin 10\%) yaitu sebesar 230 ml/menit. Selanjutnya disusul oleh sampel 3(kaolin 7\%) sebesar 223,3 ml/menit, selanjutnya pada sampel 5 (kaolin 13\%) sebesar 216,6 ml/menit. Sementara pada sampel 1 dan 2 tidak didapatkan hasil karena pecah atau ambrol saat pembuatan spesimen. Sepertihalnya pada penelitian yang dilakukan oleh Astika, dkk (2010) menjelaskan apabila kadar air bertambah, kekuatan dan permeabilitasnya akan bertambah atau naik sampai pada titik maksimal dan selanjutnya apabila kadar airnya bertambah terus maka kekuatan tekan dan permeabilitasnya akan menurun. hal ini dikarenakan ruangan antara butir - butir pasir ditempati oleh bahan pengikat yang kelebihan air sehingga kemampuan alir udara sulit untuk keluar.

Dari data penelitian diatas menjelaskan bahwa persentase kaolin berpengaruh terhadap sifat mekanik dan permeabilitas. Kaolin yang termasuk dalam kategori lempung memiliki sifat mengikat yang baik, sehingga seiring dengan bertambahnya kaolin mengakibatkan penuhnya atau menutupi pori-pori pada butiran-butiran pasir sehingga mengakibatkan menurunya permeabilitas. Varisi kaolin yang memiliki kategori paling bagus yaitu pada variasi 5 (kaolin 13\%) hal tersebut didasari karena hampir semua hasil dari variasi 5 tersebut termasuk dalam kategori standart yang telah ditentukan.

\section{SIMPULAN DAN SARAN}

\section{KESIMPULAN}

Berdasakan hasil penelitian dan pembahasan, maka dapat diambil kesimpulan sebagai berikut: (1) Pengujian komposisi kaolin Blitar menggunakan XRF menunjukan bahwa kaolin didominasi oleh kandungan silikon (Si) dengan persentase 42\% , diikuti oleh Kalium (K) 28,7\% , Besi (Fe) 25,5\%, dan diikuti oleh material lainya., (2) persentase kadar kaolin berpengaruh terhadap sifat mekanik dan permeabilitas, (3) nilai permeabilitas pada penambahan kaolin 13\% merupakan yang terendah dari tiga sampel yang terbaca hasilnya, akan tetapi sampel ini yang paling mendekati nilai permeabilitas yang sudah ditentukan yaitu $50-170 \mathrm{ml} /$ menit, (4) nilai kekuatan tarik pada cetakan pasir kering sampel 5 (kaolin 13\%) mempunyai nilai yang baik karena temasuk dalam standart nilai yang ditentukan yaitu $0,07-0,42 \mathrm{Kg} / \mathrm{Cm}^{2}$, (5 )nilai kekuatan tekan pada cetakan pasir basah sampel 3,4 dan 5 termasuk dalam kategori standart yaitu $\left(0,35-1,54 \mathrm{Kg} / \mathrm{Cm}^{2}\right)$ sedangkan pada cetakan pasir kering kekuatan kering hanya sampel 5 (kaolin 13\%) yang termasuk dalam kategori standart $\left(1,5-17,5 \mathrm{Kg} / \mathrm{Cm}^{2}\right),(6)$ nilai kekuatan geser akan bertambah seiring penambahan kadar pengikat kaolin.Pada cetakan pasir kering dan basah sampel 3,4, dan 5 termasuk dalam kategori standar kekuatan geser cetakan pasir adalah $0,10-0,49 \mathrm{Kg} / \mathrm{Cm}^{2}$.

\section{SARAN}

Berdasarkan temuan penelitian ini, maka dapat diberikan saran : (1) Bagi industri pengecoran logam, pada penelitian ini komposisi yang paling cocok dalam pembuatan cetakan pasir adalah sampel 5 dengan persentase $13 \%$, bentonit $2 \%$, pasir silika $80 \%$, dan air 5\%, selain nilai sifat mekanik yang tinggi nilai permeabilitas pada sampel mendekati standart yang sudah ditentukan dalam uji permeabilitas dan khususnya hasil digunakan sebagai estetika, (2) bagi rekayasawan penelitian ini dapat digunakan sebagai masukan atau rekomendasi bahwa kaolin dapat digunakan sebagai bahan pengikat campuran pada cetakan pasir dalam upaya mengurangi bahan pengikat tunggal bentonit yang berlebihan, (3) bagi peneliti selanjutnya, perlu diadakan penelitian lebih lanjut mengenai penelitian cetakan pasir menggunakan bahan pengikat campuran kaolin dengan komposisi yang berbeda ataupun menggunakan campuran dari jenis yang lain, (4) bagi pengembangan ilmu pengecoran logam, sebaiknya penelitian ini dapat dijadikan sebagai salah satu masukan untuk menambah pengetahuan tentang campuran pasir cetak dan sebagai bahan pertimbangan untuk penelitian - penelitian sejenis demi memaksimalkan hasil pengecoran logam yang lebih baik.

\section{DAFTAR RUJUKAN}

Arikunto, Suharsimi. 2013.Prosedur Penelitian Suatau Pendekatan Praktik . Jakarata. PT. Rineka Cipta.

Astika, I. M., Negara, D. N. K. P., \& Susantika, M. A. (2010). Pengaruh Jenis Pasir Cetak dengan Zat Pengikat Bentonit Terhadap Sifat Permeabilitas dan Kekuatan Tekan Basah Cetakan Pasir ( Sand Casting ), 4(2), 132-138.

Campuran, P., Dan, B., \& Jansen, F. (2014). Kaolin Pada Tanah Pasir Terhadap Koefisien Permeabilitas ..., (August 2016).

Garinas, W. (2009). Karakteristik Bahan Baku Kaolin Untuk Bahan Pembuatan Badan Isolator Listrik Keramik Porselen Fuse Cut Out ( Fco ). Jurnal Sains Dan Teknologi Indonesia, 11(2), 120-125. Praktikum, M., \& Ii, P. M. (2017). Laboratorium pengecoran logam.

Puspitasari, P., \& Khafiddin, A. (2014). Analisis Hasil Pengecoran Logam Al-Si Menggunakan, (2), 1-11.

Soemardji, L. (2006). Pengaruh Temperatur Tuang Dan Kandungan Silicon Terhadap Nilai Kekerasan Paduan Al-Si, 311-316.

Universitas Negeri Malang. 2017. Pedoman Penulisan Karya Ilmiah Edisi Keenam. Malang: Universitas Negeri Malang.

Yani, A., Destiarti, L., Wahyuni, N., Kimia, P. S., \& Tanjungpura, U. (2013). ISSN 2303-1077 Sintesis Zeolit A Dengan Variasi Sumber Silika Dan Alumina, 2(1), 2-7

.Zuhri, Akhmad Hamdani. 2014. Pengaruh Penggunaan Calcium Carbonate Sebagai Bahan Pengikat pada Pasir Cetak Terhadap Kualitas dan Fluiditas Hasil Pengecoran Logam Aluminium. Skripsi, Jurusan Teknik Mesin, Fakultas Teknik, Universitas Negeri Malang. 